\title{
E-COMMUNICATION TOOLS IN INTRA-ENTERPRISE COMMUNICATION IN COMPANIES OPERATING IN AUTOMOTIVE INDUSTRY IN SLOVAKIA
}

\author{
Miroslava Szarková ${ }^{1}$ \\ ${ }^{1}$ Ekonomická univerzita v Bratislave, Fakulta podnikového manažmentu, Dolnozemská 1, 85332 Bratislava, SR \\ Email: szarkova@euba.sk
}

\begin{abstract}
Communication tools are nowadays generally in literature considered to be the key factors, which influence the intra-enterprise systems and management processes. In different way, they also play a key role in terms of improving quality of the processes. Mainly modern, e-communication tools and their use in intra-enterprise communication show many results of improving the effectiveness of intra-enterprise corporate environment. They also create the environment in which employees are actively supported to be engaged in problems related to solving different assignments. In an open economy, such as Slovakia, the importance of e-communication tools in intra-enterprise communication is rising. However, the answer to the question of how employees really pay attention to this fact we tried to give in this contribution. We provide an analysis of results from monitoring ecommunication tools in small and medium sized enterprises in automotive industry in Slovakia. The aim of the article is to point out some of the chosen (ongoing) problems in use of e-communication tools in intra-enterprise communication in the selected sample of small and middle enterprises operating in Slovakia. The aim of the article isn't complex analysis of the given topic.
\end{abstract}

Keywords: e-communication tools, e-mail, Intra-company communication, intranet, web.

JEL classification: M10, M54

Doručeno redakci: 29.3.2011; Recenzováno: 9.2.2013; 7.4.2013; Schváleno k publikování: 11.9.2013

\section{Introduction}

It is generally known that communication is important part in the management system of each company. In many theoretical and professional studies Fracaro, K. (2001), Režňáková, M. (2005), Szarková, M. (2004), Szarková, M. (2011) communication is considered to be the main factor of competitiveness and profit gaining of a company. Communication is also considered to be a tool of company management, or a tool, which plays the key role in the management system of a company. Many studies from the area of management also confirm this fact Erneker, J. (2005), Szarková, M. (2004). These studies define the communication to be the main source of internal conflicts, while these can significantly influence the final competitiveness of the company (in the area of professional level).

Changes, which are the result of globalization processes, have influenced also the corporate environment in small and medium sized enterprises. Huge increase of number of small and medium sized enterprises, which emerged in the beginning of 80s in economically developed countries (nowadays even with an increasing trend in number of SMEs) has determined the migration of the workforce on the labor market. Small and medium sized enterprises, which began to offer specialized services including information services, have started to employ highly qualified professionals from different cultural environments with knowledge of different languages. This has caused a situation that the internal environment of the companies has changed a lot mainly towards cultural and language mix. At present, this process has been continued and has an impact on practically all intra-enterprise processes in automotive industry, which is core of Slovak economics. On the other side it also determines creation and development of small and middle enterprises with significant intercultural communicative character. 


\section{Analysis of results of e-communication tools used in small and medium sized enterprises operating in Slovakia}

Aim of the analysis is to describe the structure of the intra-enterprise communication mainly in relation to importance and use of e-communication tools in small and medium sized enterprises operating in Slovakia. When setting up hypotheses and research methods we analyzed facts stated in studies Roger, G. et all. (1976), where e-communication tools dynamize the internal corporate environment and help managers to react to the market changes in a flexible manner, while heading for success. Our study has been focused on the fact, if small and medium sized enterprises operating in Slovakia really use e-communication tools and also in if they see their significance in practice.

Research took place during two following phases. First phase of the researched was realized within the project VEGA no. 1/4591/07 in months January - February 2008 and was interlocked to the research of the intra-enterprise communication, which was realized within the project VEGA $1 / 8189 / 01$ in year 2002 for the topic Intra-enterprise communication and communication tools in system of enterprise management Szarková, M. (2004), from which some of the results ${ }^{1}$ were used within the frame of comparative analysis. Second phase of the research was realized two years later in the same time with the project APVV SK-CZ -010809.

Respondent sample was created by 1240 managers and employees from 15 small and medium enterprises operating in Slovakia in production (12 enterprises) and selling of supplies and spare parts for automotive industry (3 enterprises) in which number of employees do not exceed 100. Sampled enterprises had flat organization structure with twostage management. Within the framework of communication we applied Shannon's and Weaver's model of direct one-way communication without strong feedback. Respondent sample was composed of 182 managers (38 female managers), 425 business administration employees (245 females) and 633 production employees (145 females). Average age of respondents was 54, 8 years. Every sampled manager and business administration employee had a bachelor or master university education. Employees of production had high - school education. Structure of sample respondents was kept in both phases of the research. The change of the people in positions occurred in eighty - seven cases.

Research poll has been applied in two phases. Respondent sample has been set up by small and medium sized companies operating in Slovakia. Data gathering has been done by a questionnaire that consisted of 30 combined questions. This questionnaire has been sent electronically, estimating that companies had been using e-communication tools when filling in the answers. This approach has been used in order to test the skills and competencies of using e-communication tools by managers from small and medium sized companies operating in Slovakia. At the same time, the questionnaire has been the prerequisite of fast and precise analysis of the gathered data and information. The poll has been also supported by the method of half-structured interview using telephone. For the evaluation of gained data were used methods of classification, analysis, synthesis, comparative method, generalization and basic mathematical - statistical method.

Based on the analysis of the results of the first phase (2008) of the poll (two criteria frequency of usage and importance in the communication system) 4 most frequently used e-

\footnotetext{
${ }^{1}$ According to character of the respondent sample in the research in year 2002, it was able to use within the frame of comparative analysis only two indicators: use of e-communication tools in intra-enterprise communication and reasons for not using e-communication tools in intra-enterprise communication.
} 
communication tools have been outlined in the small and medium sized enterprises communication systems (see table 1).

In the second phase of the research we have been observing the following characteristics of the e-communication tools: trustworthiness of communication tool, reliability, information content and communication noise, or information bias which arose when using intraenterprise communication system. We also tried to find correlations between used communication tools and the management system in the company.

Results gained by the questionnaire method and on the phone from the selected sample of respondents - small and medium sized enterprises operating in automotive industry in Slovakia helped to formulate the following statements (gathered in table below).

One of the first results gained, based on the above mentioned methods was that in the intraenterprise communication the small and medium sized enterprises operating in Slovakia generally prefer the traditional communication methods to the e-communication tools. In spite of the fact, that the share of using e-communication tools in the research now compared to research performed in 2002 Szarková, M. (2004) increased by $15 \%$, the share of using ecommunication tools in small and medium sized enterprises operating in Slovakia also today has not exceeded $50 \%$. Only $46 \%$ of respondents stated, that in the intra-enterprise communication they use e-communication tools, mainly e-mail; $54 \%$ respondents in spite of the good information - communication system in the company nowadays use the traditional communication tools. All currently used e-communication tools are regularly used by $12.8 \%$ respondents. Only very few times they are used by $66.3 \%$ respondents. This number is based on the type of company. While in the production companies e-communication tools are not used at all, respondents from trading companies stated that they cannot operate without ecommunication tools at all. This number is important also from the point of view of using ecommunication tools in the external communication. One can assume that if small and medium sized enterprises do not use e-communication tools in the intra-enterprise communication, they are not going to use them in the external communication as well. This may cause a barrier when entering into European financial-economic structures.

Further, we have been interested in the structure of using e-communication tools in the intraenterprise flows, mainly in the basic communication levels: top-down, bottom-up or diagonally. Results are given in table 1 and 2.

Table 1: Structure of the used e-communication tools in the intra-enterprise communication in the small and medium sized companies operating in Slovakia (in \%) in first of phase of the research (2008)

\begin{tabular}{|c|c|c|c|c|c|c|c|}
\hline $\begin{array}{l}\text { e_communication } \\
\text { tool }\end{array}$ & $\begin{array}{l}\text { used regularly at } \\
\text { all } \\
\text { communication } \\
\text { levels }\end{array}$ & $\begin{array}{l}\text { used } \\
\text { regularly } \\
\text { top-down }\end{array}$ & $\begin{array}{l}\text { Is used } \\
\text { regularly } \\
\text { bottom-up }\end{array}$ & $\begin{array}{l}\text { used not } \\
\text { regularly at all } \\
\text { communication } \\
\text { levels }\end{array}$ & $\begin{array}{l}\text { used } \\
\text { irregularly } \\
\text { top down }\end{array}$ & $\begin{array}{l}\text { used } \\
\text { irregularly } \\
\text { bottom up }\end{array}$ & $\begin{array}{l}\text { used } \\
\text { accidently }\end{array}$ \\
\hline e-mail & $46.4 \%$ & $20.3 \%$ & $6 \%$ & $59.5 \%$ & $5.6 \%$ & $5.2 \%$ & $12 \%$ \\
\hline intranet & $60.6 \%$ & & & $54.1 \%$ & & & $35.1 \%$ \\
\hline Chat & $11.8 \%$ & & & $44.0 \%$ & & & $44.2 \%$ \\
\hline Web & $18.2 \%$ & & & $64.5 \%$ & & & $27.2 \%$ \\
\hline Social networks & $5.5 \%$ & & & $12.5 \%$ & & & $34.2 \%$ \\
\hline
\end{tabular}

Source: author. 
Table 2: Structure of the used e-communication tools in the intra-enterprise communication in the small and medium sized companies operating automotive industry in Slovakia (in \%) in second phase of the research (2010)

\begin{tabular}{|l|l|l|l|l|l|l|l|}
\hline $\begin{array}{l}\text { e_communication } \\
\text { tool }\end{array}$ & $\begin{array}{l}\text { It } \\
\text { regularly at all } \\
\text { communicatio } \\
\text { n levels }\end{array}$ & $\begin{array}{l}\text { It used } \\
\text { regularly } \\
\text { top-down }\end{array}$ & $\begin{array}{l}\text { It is used } \\
\text { regularly } \\
\text { bottom-up }\end{array}$ & $\begin{array}{l}\text { It used not It is used } \\
\text { regularly at all is used } \\
\text { communication } \\
\text { levels }\end{array}$ & $\begin{array}{l}\text { It is used } \\
\text { accidently } \\
\text { irregularly } \\
\text { top down } \\
\text { bottom up }\end{array}$ & \\
\hline e-mail & $72,4 \%$ & $48,3 \%$ & $12 \%$ & $59,5 \%$ & $5,6 \%$ & $5,2 \%$ & $7,5 \%$ \\
\hline intranet & $62,0 \%$ & & & $54,9 \%$ & & & $36,2 \%$ \\
\hline Chat & $11,9 \%$ & & & $44,0 \%$ & & $28,6 \%$ \\
\hline Web & $19,0 \%$ & & & $64,5 \%$ & & & $27,6 \%$ \\
\hline Social networks & $35,8 \%$ & & & $12,5 \%$ & & & $45,2 \%$ \\
\hline
\end{tabular}

Source: author

Analysis of the structure of using individual e-communication tools showed an interesting fact, that the combination of traditional and e-communication tools in the intra-enterprise communication of small and medium sized enterprises is still surviving. In the bottom-up communication respondents stated that e-communication tool, for example e-mail, has been used only after verbal or written (in paper) requirement. More detailed analysis of communicated contents also showed, that top-down e-communication tools have been used mainly in rules, methodical materials, information, and communication documents which required only a minimal feedback. At the bottom-up communication level, the ecommunication tools have been used mainly for communicating preparatory materials in order to write or finish text messages, or fill in the questionnaires.

Poll results proved, that in the small and medium sized enterprises operating in Slovakia, mainly traditional communication tools are used in spite of the fact that the equipment of the companies with the communication information systems has been at high level (all companies have purchased IKT, $98 \%$ of companies have been equipped by complete and operating IKT). ${ }^{2}$ We assume that this relates to the use of communication stereotypes in the intraenterprise communication systems, also in the management systems of companies. This fact can also arise from existing rigid communication skills at the management level, and also from a certain level of fear of using e-communication tools. For example the analysis of the main reasons, which respondents stated as very important mainly at the management level, showed that (table 3) 82, $12 \%$ of employees feared of improper use of electronic identity, 95, $42 \%$ of employees feared of pc viruses and 94, $32 \%$ of employees stated that it has no sense to send internal materials through intranet, because they have to print them out and it also takes time, so it is the same as if they had got them through internal post. Results of the research from the year 2010 correspond with the results from the year 2002 Szarková, M. (2004), Výročné správy (2008-2010).

\footnotetext{
${ }^{2}$ In some companie employees must not have used the e-communication tools for the purpose of intra-enterprise communication. In the sample of respondents there have been companies that did not have any e-communication tools introduced into activity, they had them stored. Majority of respondents used the e-communication tools only in relation to external, mainly inter-enterprise communication.
} 
Table 3: Reasons of not using e-communication tools in the intra-enterprise communication

\begin{tabular}{|c|c|c|c|c|c|c|c|c|c|}
\hline $\begin{array}{l}\text { Reasons of not } \\
\text { using e- } \\
\text { communication } \\
\text { tools in the } \\
\text { intra-enterprise } \\
\text { communication } \\
\text { - based on the } \\
\text { analysis of } \\
\text { answers from } \\
\text { respondents }\end{array}$ & $\begin{array}{l}\text { Electricit } \\
\text { y outflow } \\
\text { and fear } \\
\text { of losing } \\
\text { data }\end{array}$ & $\begin{array}{l}\text { Problems } \\
\text { with using } \\
\text { hardware }\end{array}$ & $\begin{array}{l}\text { Problems } \\
\text { with } \\
\text { using } \\
\text { software }\end{array}$ & $\begin{array}{l}\text { Not } \\
\text { wanted } \\
\text { e-mails } \\
\text { (SPAM) }\end{array}$ & $\begin{array}{l}\text { Problems } \\
\text { with } \\
\text { intranet }\end{array}$ & $\begin{array}{l}\text { Fear of } \\
\text { losing } \\
\text { electronic } \\
\text { identity }\end{array}$ & $\begin{array}{l}\text { Requireme } \\
\text { nt to print } \\
\text { out the } \\
\text { material }\end{array}$ & $\begin{array}{l}\text { Fear of } \\
\text { spams } \\
\text { and } \\
\text { viruses }\end{array}$ & $\begin{array}{l}\text { Other } \\
\text { reasons: } \\
\text { my legs } \\
\text { are still } \\
\text { faster } \\
\text { than my } \\
\text { PC, some } \\
\text { messages } \\
\text { need } \\
\text { emotions, } \\
\text { and so } \\
\text { on. }\end{array}$ \\
\hline$\%$ & $22.54 \%$ & $63.13 \%$ & $62.14 \%$ & $\begin{array}{l}58.68 \\
\%\end{array}$ & $38.63 \%$ & $82.12 \%$ & $94.32 \%$ & $\begin{array}{l}95.43 \\
\%\end{array}$ & $18.43 \%$ \\
\hline
\end{tabular}

Source: author.

\section{Conclusion}

The research showed that using non-traditional e-communication tools has been influenced by decisions $^{3}$ and rules for using modern communication tools in the intra-enterprise communication system, education of employees, their age and sex. $53 \%$ respondents also use intranet/internet besides traditional communication tools. If there is a change in characteristics of communication tools used in the intra-enterprise communication system, respondents stated that they would not have any problem to use e-communication tools. This moment has also been supported by the statement that the current market development needs communication in a flexible and effective way also in the inside of a company.

Research results further showed that non-traditional e-communication tools are not used or there are problems of using them in $54 \%$ of respondents. In a deeper analysis is has been observed that this group of respondents has been set up by $96 \%$ respondents of higher age than 45 , while only a slightly higher number (higher by $2,56 \%$ ), has been observed in small enterprises.

This research showed that taking advantage of traditional communication tools in the intraenterprise communication is mainly driven by the communication types or processes going on in the internal closely related social context of personal relationships formal or informal. The research showed that the structure of use of e-communication tools in intra-enterprise communication is changing gradually. For example use of the social networks is increasing (in the time frame of two years increased use of social networks in $11 \%$, the research also showed that this e-communication tool started to use mainly administration employees and managers).

Even though, the results of the research made in year 2008 Szarková, M. (2008) and in 2010 compared to the results from year 2002 Szarková, M. (2004) basically confirmed definite specific tendency of the progress in using e-communication tools in small and medium enterprises operating in Slovakia, they concurrently pointed out, that intra-enterprise environment of small and medium enterprises operating in Slovakia are changing only very slowly in the term of using e-communication tools. They keep using stereotypes of intraenterprise communication based on preference of semiformal and traditional "paper"

\footnotetext{
3 "Force" has been connected to the requirement of the change of working stereotypes, which are closely related to the use of certain communication tools. In the companies, where information Technologies have begun to beused, respondents have learned to use e-communication tools despite they really understood their advantages
} 
communication tools, which could be one of the causes of their slowed flexibility and adaptability on the market mainly during economic crisis.

\section{Acknowledgement}

This research has been based on the projects VEGA 1/4591/07 Metodologické východiská výberu komunikačných nástrojov v podnikatel'ských aktivitách malých a stredných podnikov v SR v podmienkach interkultúrneho trhu EÚ and APVV SK-CZ -0108-09 Vplyv finančných trhov na finančné riadenie podnikov pôsobiacich v SR a ČR v kontexte súčasných globálnych procesov.

\section{References}

[1] ERNEKER, J., 2005. Řízení a komunikační dovednosti. České Budejovice: Vysoká škola evropských a regionálních studií. ISBN 80-86708-13-6.

[2] FRACARO, K., 2001. Empathy:a potent management tool. In: Supervision (3).

[3] GERTLER, L'., 2004. Nové trendy v teórii merania a riadenia rizika. In: Ekonomické rozhl'ady, roč. XXXIII, (2), 245 - 253. ISSN 0323-262X.

[4] MICHALOVÁ, V., 2005. Obchodné služby, ich postavenie a úloha v ekonomike. In.: Obchodné služby, ich úloha a prínos do ekonomiky Slovenska a jej konkurencieschopnosti $\mathrm{v}$ etape integrácie do európskeho trhu. Bratislava: Vydavatel'stvo EKONÓM. ISBN 80-225-2117-5.

[5] REŽŇÁKOVÁ, M., 2005. Má komunikace význam pro finanční řízení? In: Marketingová panoráma, ( 1 - 2), 6 - 8. ISSN 1336-1864.

[6] ROGER, G., M. ROGERS-EVERETT and R. AGARWALA-ROGERS, 1976. Communication in Organizations. New York: Free Press. ISBN 0-02-926710-2.

[7] SAMMALISTO, K. and T. BRORSON, 2008. Training and Communication in the Implementation of Enviromental Management Systems (ISO 14001). In: Journal of Cleaner Production. February, Vol. 16 (3).

[8] SZARKOVÁ, M. a kolektív, 2004. Vnútropodnikové komunikačné toky a nástroje $\mathrm{v}$ systéme riadenia podniku. Zborník príspevkov $\mathrm{z}$ medzinárodného vedeckého kolokvia pri príležitosti ukončenia výskumnej úlohy VEGA č.1/8189/1. Bratislava: Vydavatel'stvo EKONÓM. ISBN 978-80-225-3049-1.

[9] SZARKOVÁ, M., 2008. Komunikačné nástroje v systéme riadenia podniku. Bratislava: Vydavatel'stvo EKONÓM. ISBN 978-80-225-2525-1.

[10] SZARKOVÁ, M., 2011. Komunikácia v manažmente. Bratislava: Vydavatel'stvo EKONÓM. ISBN 978-80-225-3251-8.

[11] VÝROČNÉ SPRÁVY slovenských podnikov a podnikov podnikajúcich na území SR za roky 2008 a 2010. http://www.mpiweb.org/media/home/pressrelease.asp?id=256, 2.9.2004: Event Marketing Tops List of Marketing Tactics for ROI. 